solution, but in other respects the above statements will hold true.

The kind of dish used, the temperature of the evaporation, the presence of free hydrochloric acid and free sulphuric acid, dic not appear to influence the results.

A method based on the evaporation of dilute solutions, drying the potassium platinichloride at $100^{\circ}$, and the use of the factors 0.30688 for potassium chloride and 0.1939 for potassium oxide, gave good results and is beliered to be more satisfactory for scientific and practical reasons, than the method of Fresenius, in which the platinum solution is added to concentrated solutions, the double salt is dried many hours at $130^{\circ} \mathrm{C}$. and the factors 0.3056 and 0.19308 are used.

\title{
THE INDIRECT ANALYSIS OF MIXTURES CONTAINING A COMMON CONSTITUENT.
}

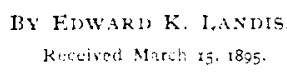

ALCULATION of mixtures containing a common constituent.

Data giaen:

Weight of mixture.

Weight of common constituent in mixture.

Let $x=$ one salt.

Let $y=$ the other.

Let $a=$ amount of common constituent in one part of $x$. Let $b=$ amount of common constituent in one part of $y$. Let $z=$ weight of mixture.

Let $Q=$ weight of common constituent in mixture.

To find ralues of $x$ and $y$;

$x+y=z$.

$a x+b y=Q$.

$a\left(z-y^{\prime}\right)+b y^{\prime}=Q$.

$a z-a y+b y=Q$.

$b^{\prime}-a y^{\prime}=Q-a z$.

$y=\frac{Q-a z}{b-a}$ and $x=z-y$. 
SECOND METHOD.

Same data. Calculate the weight of salt of greatest molecular weight if entire amount of common constituent were combined with it. Subtract from this the weight of the mixture. This difference is proportional to the amount of salt of least molecular weight contained in the mixture. Therefore, form the proportion

$\left(\begin{array}{c}\text { Molecular weight } \\ \text { heaviest }\end{array}\right)-\left(\begin{array}{c}\text { Molecular weight } \\ \text { lightest }\end{array}\right):\left(\begin{array}{c}\text { Difference } \\ \text { found above }\end{array}\right)$ $::\left(\begin{array}{c}\text { Molecular weight } \\ \text { lightest }\end{array}\right): x$.

$x=$ amount of salt of least molecular weight contained in the mixture.

INDIRECT ANALYSIS:

Example. Method No. I.-A sample of $\mathrm{NaHCO}_{3}$, containing $\mathrm{Na}_{2} \mathrm{CO}_{3}$, gave $97.2 \mathrm{I}$ per cent. of the mixed carbonates, and 50.98 per cent of $\mathrm{CO}_{2}$.

$\mathrm{NaHCO}=0.5238095 \mathrm{CO}_{2}$.

$\mathrm{Na}_{2} \mathrm{CO}_{3}=0.4 \mathrm{I} 50943 \mathrm{CO}_{2}$.

Let $x=$ per cent. $\mathrm{NaHCO}_{3}$.

Let $y=$ per cent. $\mathrm{Na}_{2} \mathrm{CO}_{3}$.

Then $a=0.5238095$.

$b=0.4150943$.

$z=97.71$.

$Q=50.98$.

$x+y=97.71$.

$x=(97.7 \mathrm{I}-y)$.

$0.5238095 x+0.4150943 y=50.98$.

$0.5238095(97.7 \mathrm{I}-y)+0.4150943 y=50.98$.

5 I.1814-0.5238095y+0.41 50943y $=50.98$.

$0.1087152 y=0.2014$.

$y=\mathrm{r} .85254=$ per cent. $\mathrm{Na}_{2} \mathrm{CO}_{3}$.

$x=95.85746=$ per cent. $\mathrm{NaHCO}_{8}$.

Proof:

$$
\begin{array}{r}
1.85254 \times 0.4150943=0.76897 \\
95.85746 \times 0.5238095=\frac{50.21104}{50.98001}
\end{array}
$$


Example. Method No. 2.-Same data as before.

Molecular

weirht.

Molecular Amount
weight.

$\mathrm{CO}_{n} ;$ per cent. $\mathrm{CO}_{2}$ found $=\mathrm{NaHCO}_{3}: x$.

44: $\quad 50.98=84: 97.3255$.

$97.7 \mathrm{I}-97.3255=0.3845$.

$\left(\begin{array}{c}\text { Molecular weight } \\ \mathrm{Na}_{42} \mathrm{CO}\end{array}\right)-\left(\begin{array}{c}\text { Molecular weight } \\ \mathrm{NaHCO}_{3}\end{array}\right):\left(\begin{array}{c}\text { Difference } \\ \text { found }\end{array}\right)$

$=\left(\begin{array}{c}\text { Molecular weight } \\ \mathrm{Na}_{3} \mathrm{CO}_{3}\end{array}\right):\left(\begin{array}{c}\text { Per cent. } \mathrm{Na}_{2} \mathrm{CO}_{3} \\ x\end{array}\right)$

$2 z: 0.3845=106: 1.852$.

$\mathrm{Na}_{3} \mathrm{CO}_{3}=\mathrm{I} .852$ per cent.

$\mathrm{NaHCO}_{3}=95.85^{8}$ per cent.

Proof:

$$
\begin{array}{r}
1.852 \times 0.4150943=0.76875 \\
95.858 \times 0.5238095=\frac{50.2 \mathrm{II} 33}{50.98008}
\end{array}
$$

\section{ACCURACY OF THE DYEING TEST.}

BY CHAKLES S. BOYER.

keccived April 8, 1895.

THE accuracy and value of the laboratory dyeing test of the natural organic dyestuffs, such as logwood, etc., is a much mooted question among those engaged in the dyestuff trade. Some hoid that the dyeing test is only of value where the dyestuff is to be used in exactly the same manner as the laboratory test, and since about every dyer has his own modifications of the general method of dyeing with the dyestuff the test is useless except for special cases. Still others hold that the dyeing test never gives the actual value of the dyestuff.

'o ascertain the accuracy of the dyeing test the writer made a series of comparative dyeing tests, and also analyzed the dyestuffs according to the best methods of analytical chemistry now known. For these tests several samples of logwood and extract of sumac were used.

Logwood.-Fifty grams each of two different samples of thoroughly dried chipped "St. Marc" logwood were repeatedly extracted with water and the weak liquor evaporated to one 